\title{
The Cambrian Ross Orogeny in northern Victoria Land (Antarctica) and New Zealand: A synthesis
}

\author{
L. Federico, ${ }^{1}$ G. Capponi, ${ }^{1}$ L. Crispini, ${ }^{1}$ and J. D. Bradshaw ${ }^{2}$ \\ ${ }^{1}$ Dip.Te.Ris., University of Genova, C.so Europa 26, 16132, Genova, Italy (federico@dipteris.unige.it) \\ ${ }^{2}$ Department of Geological Sciences, University of Canterbury, Christchurch, New Zealand
}

\begin{abstract}
In the Cambrian, the paleo-Pacific margin of the Gondwana supercontinent included East Antarctica, Australia, Tasmania and New Zealand and was affected by the major Ross-Delamerian Orogeny. In Antarctica, evidence suggests that this resulted from oblique subduction and that in northern Victoria Land it was accompanied by the opening and subsequent closure of a back-arc basin. Comparison of the type and timing of sedimentary, magmatic and metamorphic events in areas noted above shows strong similarities between northern Victoria Land and New Zealand. In both regions Middle Cambrian volcanites are interpreted as arc/back-arc assemblages produced by westdirected subduction; sediments interbedded with the volcanites show provenance both from the arc and from the Gondwana margin and therefore place the basin close to the continent. Back-arc closure in the Late Cambrian was likely accomplished through a second subduction system.
\end{abstract}

Citation: L. Federico, G. Capponi, L. Crispini, and J.D. Bradshaw (2007), The Cambrian Ross Orogeny in northern Victoria Land and New Zealand: A synthesis, in Antarctica: A Keystone in a Changing World - Online Proceedings of the 10th ISAES, edited by A.K. Cooper and C.R. Raymond et al., USGS Open-File Report 2007-1047, Short Research Paper 063, 5 p.; doi:10.3133/of2007-1047.srp063

\section{Introduction}

The formerly adjacent northern Victoria Land, Antarctica, Tasmania, SE-Australia and New Zealand contain fragments of a Cambrian orogen known as RossDelamerian Orogeny, but contrasting models have often been proposed in each sector (e.g., Weaver et al., 1984; Kleinschmidt and Tessensohn, 1987; Münker and Crawford, 2000; Ferraccioli et al., 2002; Squire and Wilson, 2005; Foster et al., 2005; Federico et al., 2006; Gutjahr et al., 2006).

We compare timing and type of magmatic, sedimentary, metamorphic and deformation events in areas noted above and identify striking similarities between northern Victoria Land (NVL) and the Takaka Terrane of New Zealand (NZ). Especially new geochemical data on clasts from Middle Cambrian conglomerates in New Zealand suggest a correlation with a coeval basin in northern Victoria Land. We summarize the main features in common and discuss the tectonic evolution of the NVL-New Zealand sector of the margin.

\section{Cambrian geology}

\section{Northern Victoria Land (Antarctica)}

NVL (Fig. 1a) includes three terranes: the Wilson Terrane, the Bowers Terrane and the Robertson Bay Terrane. The Wilson Terrane is made up of metasedimentary rocks with bodies of mafic and ultramafic rocks (including eclogites) at the boundary with the Bowers Terrane (Ricci et al., 1996; Capponi et al., 1997). Eclogites contain relic coesite and therefore formed at peak pressures of $>2.9 \mathrm{GPa}$ (Ghiribelli et al., 2002; Palmeri et al., 2007). They record UHP metamorphism at c.a. $500 \mathrm{Ma}$ and show geochemical affinities variable from E-MORB to T-MORB to orogenic calc-alkaline (Di Vincenzo et al., 1997). The Wilson Terrane is intruded by a Cambro-Ordovician calc-alkaline plutonic suite with magmatic arc affinity (Granite
Harbour Intrusives). The oldest granitoids of this suite have been dated at $544 \pm 4 \mathrm{Ma}$ and $535 \pm 26 \mathrm{Ma}$ (Stump, 1995 and references therein).

The low-grade Bowers Terrane comprises the Sledgers, the Mariner and the Leap Year Groups. Within the Sledgers Group, the Glasgow Volcanics are primarily basalt and andesites with subordinate felsic volcanics.
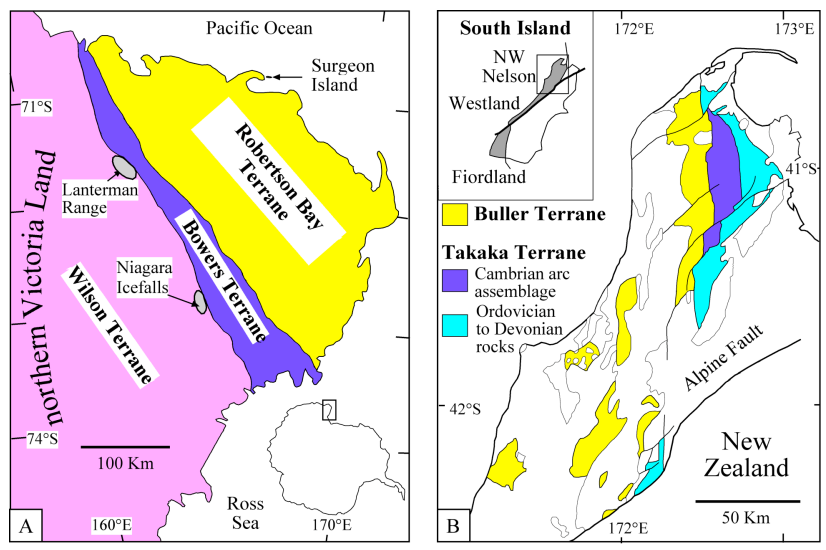

Figure 1. Schematic geological map of the studied areas.

They are intercalated with the metasedimentary Molar Formation. Their affinity with N-MORB, E-MORB, TMORB, arc tholeiite, calc-alkaline and OIB magmas (Rocchi et al., 2003) point to an arc/back-arc setting. The Molar Formation is made up of fine sandstone and shales, with interbeds of polymict conglomerates, with clasts of mafic / ultramafic rocks to felsic rocks. Basset et al. (2001) reported an age of $511 \pm 7 \mathrm{Ma}$ for a granitoid clast. A mixed continental (probably the Wilson Terrane)/ primitive magmatic arc source of the Molar Formation is supported by chemical and isotopic data (Henjes-Kunst and Schüssler, 2003) and is consistent with a back-arc 
setting. The late Middle / early Upper Cambrian Mariner Group records the progressive infilling of a basin and the end of volcanic activity. The unfossiliferous marine to continental Leap Year Group is in sharp and weakly discordant contact with the Mariner Group.

The Robertson Bay Terrane consists of a thick sequence of very low-grade turbidites whose base is unexposed. A Cambro-Ordovician age (Wright et al., 1984; Henjes-Kunst, 2003) and a metamorphic continental source (Stump, 1995; Henjes-Kunst and Schüssler, 2003) are inferred. The nature of the original basement is unknown but Federico et al. (2006) suggest that it could be oceanic crust. These turbidites possibly record sedimentation in a marginal basin, in light of evidence for a subduction zone outboard (Fioretti et al., 2005). Since ages of both sedimentation and deformation of the Robertson Bay Terrane are still ambiguos, its possible relation to the Ordovician Lachlan Orogeny cannot be excluded (see Bradshaw, this congress). The presence of granulites in cored bombs of the Cenozoic McMurdo Volcanics (Rocchi et al., unpubl. data) and of crustal xenoliths inside the Devonian Admiralty Intrusives (GANOVEX Team, 1987) suggest that crustal elements may be presently buried under the pile of Robertson Bay turbidites. These possibly outcrop at Surgeon Island (see discussion in Fioretti et al., 2005).

\section{New Zealand}

Cambrian rocks of NZ outcrop in the Takaka Terrane (Fig. 1b) and comprise both volcanic and sedimentary rocks. The Takaka Terrane is composed of at least 13 north-south trending fault slices, each with a more-or-less coherent internal stratigraphy that differs somewhat from that of the other fault slices (Münker and Cooper, 1999). The fault slices represent relics of an arc to back-arc transect (Münker and Cooper, 1999). The Cambrian arc to back-arc rocks (Devil River Volcanics Group) are subdivided into the older Mataki Volcanics, the Cobb Igneous Complex and the Benson Volcanics.

The Mataki Volcanics comprise mainly tholeiitic basalts, possibly of back-arc setting. The Cobb Igneous Complex comprises gabbros and ultramafites of boninitic composition. A U/Pb zircon SHRIMP age of $515+7 \mathrm{Ma}$ has been obtained from a plagiogranite cutting the complex (C. Münker, T. Ireland and S. Weaver, quoted in Münker and Cooper 1999). The late Middle Cambrian Benson Volcanics comprise a calc-alkaline suite of basaltic to andesitic composition.

Trace element and isotopic compositions of Devil River Volcanics Group rocks are very variable (e.g., $\varepsilon \mathrm{Nd}$ ranges from -5 to +6 and initial $87 \mathrm{Sr} / 86 \mathrm{Sr}$ (at $500 \mathrm{Ma}$ ) ranges from 0.703 to 0.712 ; Münker, 2000).

The Devil River Volcanics Group interfingers with the Haupiri Group, a Middle to Upper Cambrian (?) sedimentary sequence made up of fine sandstone and siltstone with bodies of conglomerates. The sequence ends with the thick polymict Lockett Conglomerate. It contains clasts of chert, mafic and felsic volcanics, granitoids, ultramafics and sandstone. A recent geochemical study on the conglomerate clasts (Gutjahr et al., 2006) identified a continental source for the metagranitic and sandstone clasts and an intra-Devil River arc source for the ultramafic to intermediate igneous clasts.

In Fiordland more strongly metamorphosed Takaka Terrane rocks occur, including a high-grade metasedimentary sequence intruded by a 480 Ma granite (Gibson and Ireland, 1996).

Table 1. Correlation chart of magmatic, sedimentological and tectonic events in Cambro-ordovician time in northern Victoria Land and New Zealand. Cambrian boundaries according to the International Stratigraphic Chart (2004). Data used in the table: ANTARCTICA: Cooper et al. (1996); Di Vincenzo et al. (1997); Stump (1995).

NEW ZEALAND: Gibson and Ireland (1996); Gutjar et al. (2006); Jongens et al. (2003); Münker and Crawford (2000).

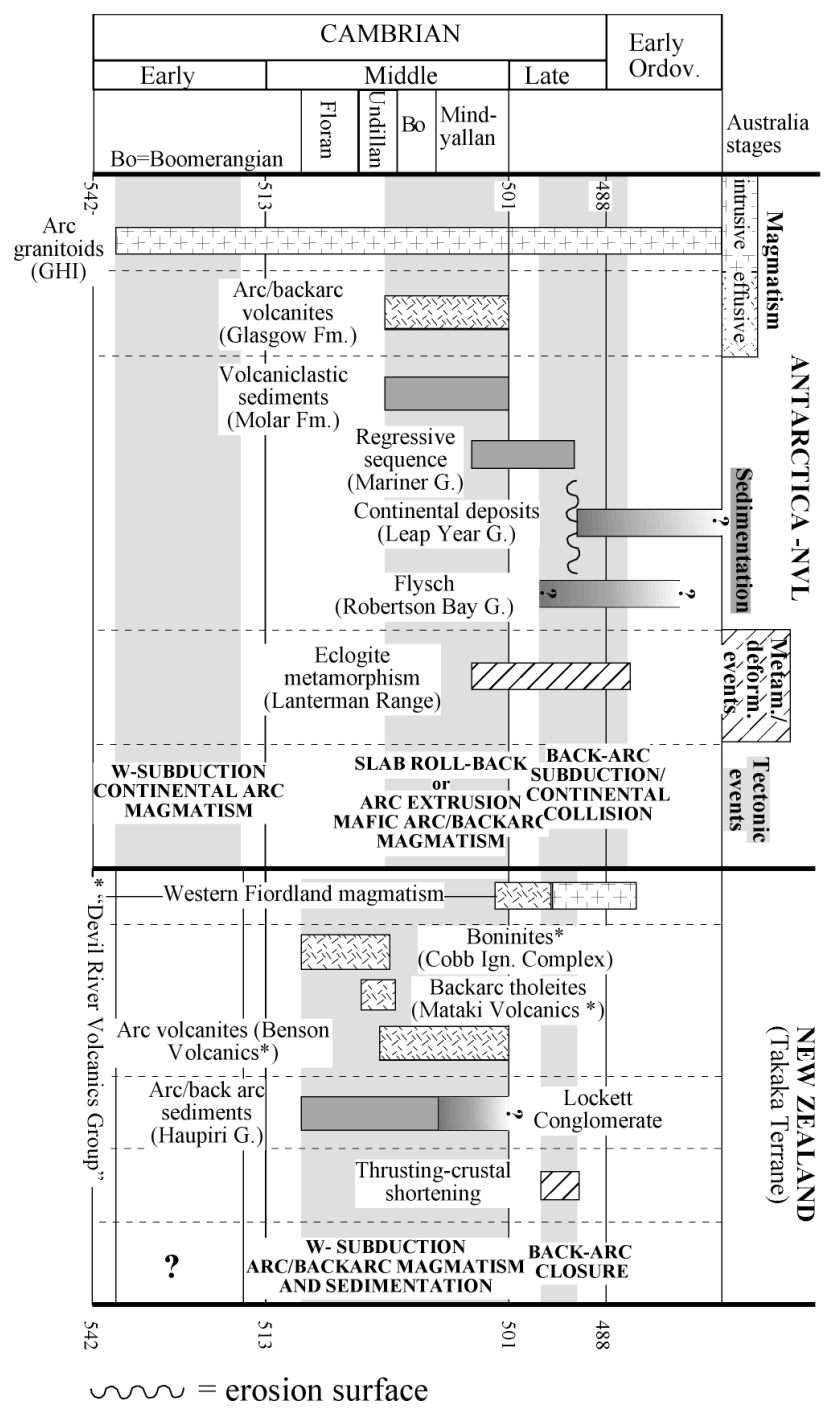




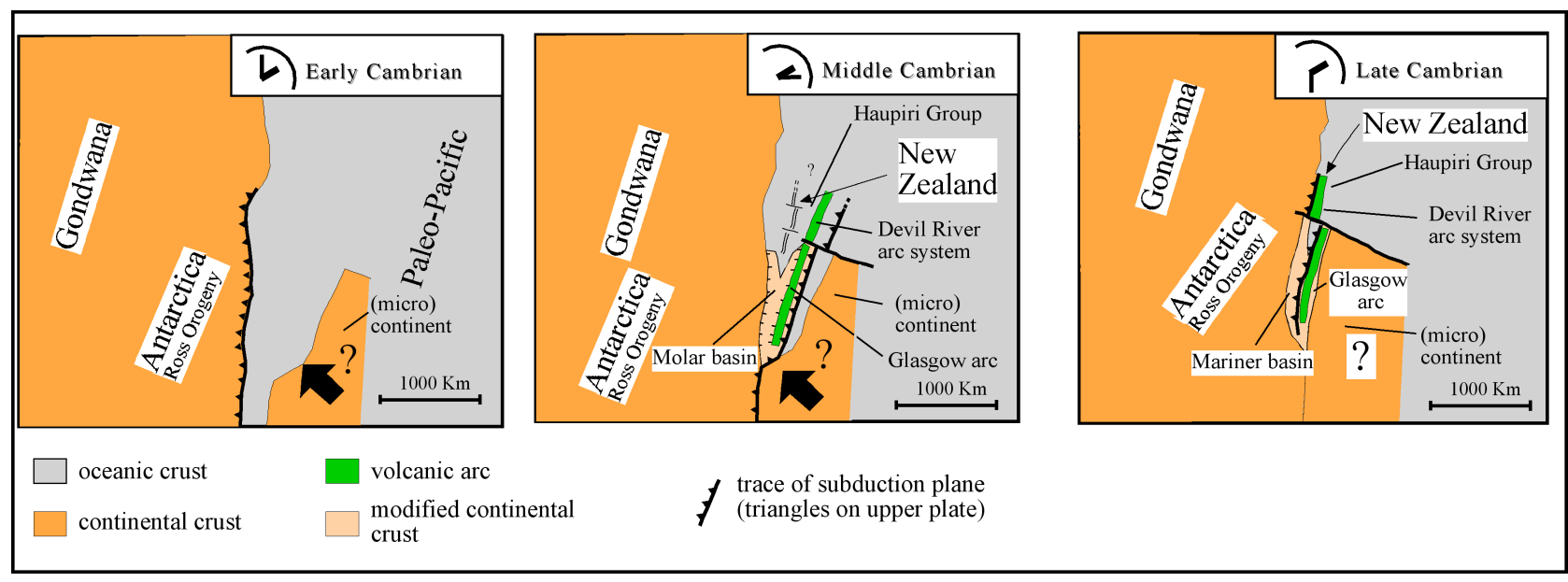

Figure 2. Proposed paleogeographic reconstruction of the NVL - NZ sector of the paleo-Pacific Gondwana margin in: a) Early Cambrian: westward subduction; b) Middle Cambrian: back-arc basin opening ; c) Late Cambrian: back-arc basing closure, probably following collision of a buoyant element (continental or oceanic) in the Antarctic segment.

\section{Discussion}

Detailed comparison of Cambrian events in SE Australia, Tasmania and Antarctica reveals significant along-trend differences in the Ross-Delamerian tectonic evolution, with stronger similarities between the NVL and NZ sectors (Table 1). Most authors agree that Victoria Land (Antarctica) was affected by W-directed subduction (e.g. Kleinschmidt and Tessensohn, 1987; Weaver at al., 1984; Ferraccioli et al., 2002). Westward subduction in the NZ sector is supported by new geochemical data (Münker and Cooper, 1999; Gutjahr et al., 2006). Recent work in NVL and NZ points to the development of a back-arc basin that opened and closed in the Middle to 2006). Evidences of this event includes: the back-arc basin affinities of Middle Cambrian volcanites and the early Late Cambrian (Federico et al., 2006; Gutjahr et al., presence of coarse-grained sediments deposited in the back-arc and supplied from the continental margin. A period of extension along the paleo-Pacific margin of Gondwana around 504-500 Ma has been recognized also by Squire and Wilson (2005). In NVL closure of this basin was possibly caused by the initiation of a second subduction zone between the back-arc basin and the continent. The collision of a continental mass, suggested by Federico et al. (2006) in view of the evidence of continental crust buried under the Robertson Bay turbidites (discussed above), is still a subject of debate. Alternatively, this could be replaced by a bouyant oceanic feature. This mass could represent a continental ribbon previously carved off the Gondwana margin. Subduction of the back-arc basin was suggested by Gutjar et al. (2006) for the NZ sector.

\section{A possible NVL -NZ correlation}

A possible reconstruction of the Ross tectonic evolution in NVL and NZ is summarized in the following (Fig. 2 and Fig. 3):
Early Cambrian: oblique westward subduction was active in the Antarctic sector, producing the continental magmatic arc of oldest Granite Harbour Intrusives. Oblique convergence has been widely supported (e.g. Rocchi et al., 1998; Capponi et al., 1999; Ferraccioli et al., 2002), and many suggest that there was continental crust in displaced terrane(s) on the lower plate (e.g. Squire and Wilson, 2005). No Early Cambrian events are recorded in NZ, apart from the occurrence of volcanic clasts (mainly boninites and arc tholeites) in MidCambrian conglomerates (Münker and Cooper, 1999).

Middle Cambrian: in the NVL - NZ sector, a back-arc basin opened, probably because of the roll-back of the subducting slab (Federico et al., 2006; Squire and Wilson, 2005). The back-arc basin had an oceanic nature in the NZ sector (Münker and Crawford, 2000), whereas in NVL this is still debated (see discussion in Federico et al., 2006).

Late Cambrian: in NVL and NZ the closure of the back-arc basin occurred and resulted in high-pressure metamorphism and deformation in NVL. The wide range of geochemical affinities of both the eclogites and the arc/back-arc Glasgow Volcanics could support a genetic link between these rocks (see discussion in Federico et al., 2006). In NZ the back arc subduction (cf. Gutjar et al., 2006) was accompanied by crustal shortening, which emplaced the arc assemblage over the accretionary complex; this event was probably coeval with the deposition of the Lockett Conglomerate and was followed by the emplacement of the Balloon Melange (Jongens et al., 2003). The reorganization of the convergent margin may have been driven either by the collision of a continental ribbon (Federico et al., 2006 and cited references) situated on the lower plate, or by the arrival of an oceanic plateau, or by introduction of buoyant young ocean crust entering the subduction zone. 


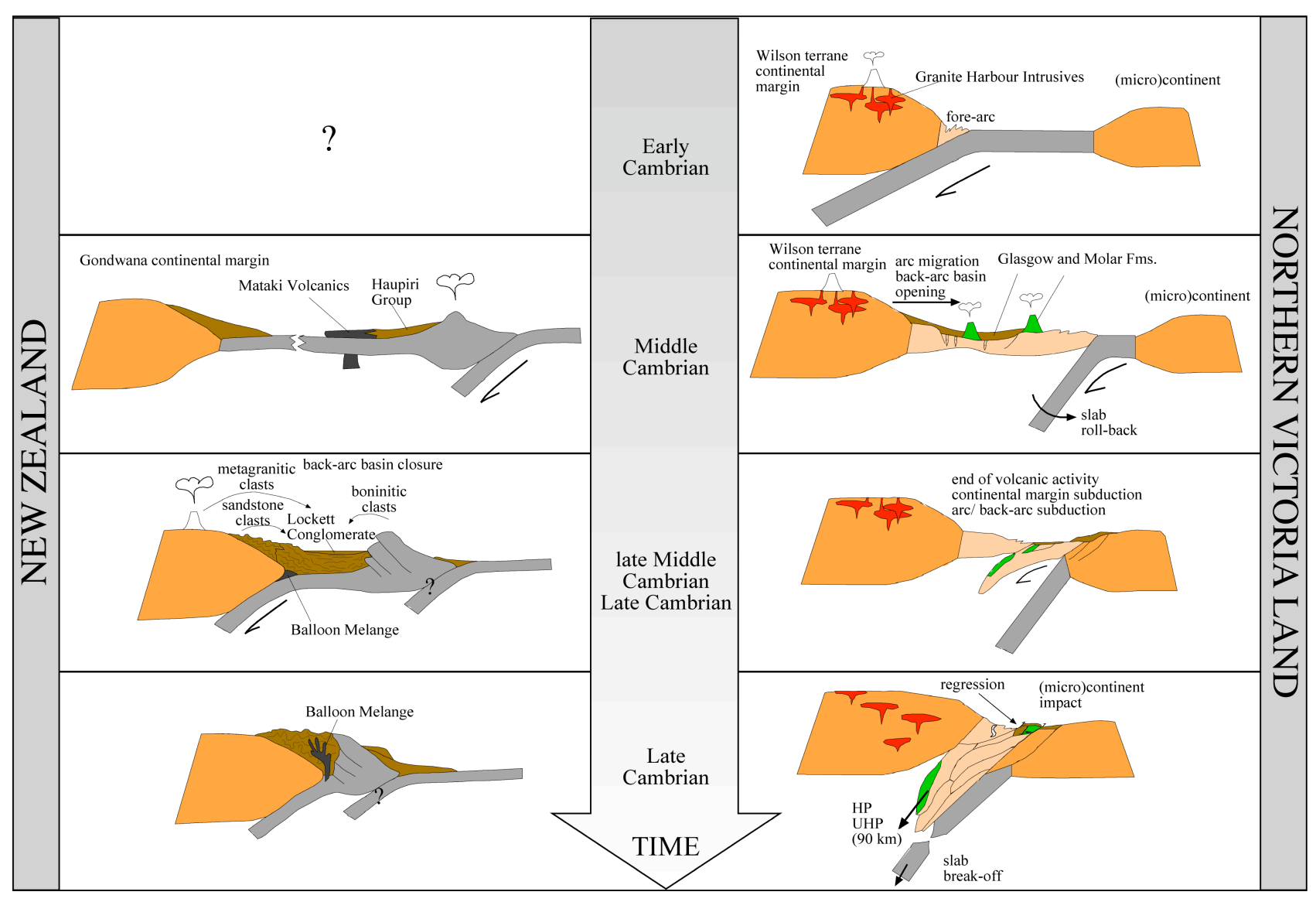

Figure 3. Cambrian tectonic evolution in NVL and NZ (modified after Federico et al., 2006 and Gutjar et al., 2006). See text for details.

\section{Summary}

Key similarities that exist between NVL and NZ in Cambro-ordovician tectonics are:

- Both were affected by westward subduction, established in NVL already in the Lower Cambrian, whereas in NZ first clear evidences of a subduction setting are of Middle Cambrian time;

- In both areas a back-arc basin opened and hosted sedimentary successions marked by both a primitive magmatic and a mature continental source;

- Closure of the back-arc basin, due to development of a second subduction zone outboard, occurred in both areas in the Late Cambrian.

This relationship can be explained by a paleogeographic reconstruction that places NZ close to the Gondwana margin in Cambrian times (as suggested by Gutjar et al. 2006), sharing a common tectonic evolution with the NVL sector of the Ross Orogeny.

Acknowledgments. This work benefitted from the logistical and financial support of the Programma Nazionale di Ricerche in Antartide (PNRA, Italy) and from a scholarship of the University of Genova to
L.F. Comments by C. Siddoway and by W. LeMasurier significantly improved the paper.

\section{References}

Bassett, K.N., S. Weaver, J.D. Bradshaw, and T. Ireland (2001), Conglomerate Provenance and Geochronology: Dating the Accretion of an Intra-Oceanic Arc, Bowers Terrane, Antarctica, Eos (Transactions, American Geophysical Union), 82(47), Abstract V41C01.

Capponi, G., D. Castelli, A.M. Fioretti, and G. Oggiano (1997), Geological mapping and field relationships of eclogites from the Lanterman Range (Northern Victoria Land, Antarctica), in The Antarctic Region: Geological evolution and Processes, edited by C.A. Ricci, pp. 219-225, Terra Antarctica Publication, Siena.

Capponi, G., L. Crispini, and M. Meccheri (1999), Structural history and tectonic evolution of the boundary between the Wilson and Bowers terranes, Lanterman Range, northern Victoria Land, Antarctica, Tectonophysics, 312, 249-266.

Cooper, R.A., J.B. Jago, and J.G. Begg (1996), Cambrian trilobites from Northern Victoria Land, Antarctica, and their stratigraphic implications, NZJGG, 39, 363-387.

Di Vincenzo, G., R. Palmieri, F. Talarico, P.A. Andriessen, and C.A. Ricci (1997), Petrology and Geochronology of eclogites from the Lanterman Range, Antarctica, J. Petrol., 38, 1391-1417.

Federico, L., G. Capponi, and L. Crispini (2006), The Ross orogeny of the Transantarctic Mountains: a northern Victoria Land perspective, Int. J. of Earth Sci., DOI: 10.1007/s00531-005-0063-5

Ferraccioli, F., E. Bozzo, and G. Capponi, (2002), Aeromagnetic and gravity anomaly constraints for an early Paleozoic subduction system 
of Victoria Land, Antarctica, Geophys. Res. Lett., 29(10), $10.1029 / 2001$ GLO14138.

Fioretti, A.M., G. Capponi, L.P. Black, R. Varne, and D. Visona' (2005), Surgeon Island granite SHRIMP zircon ages: a clue for the Cambrian tectonic setting and evolution of the Paleopacific margin of Gondwana (northern Victoria Land, Antarctica), Terra Nova, 17(3), 242-249.

Foster D.A., D.R. Gray, and C. Spaggiari (2005), Timing of subduction and exhumation along the Cambrian East Gondwana margin, and the formation of Paleozoic backarc basins, GSA Bulletin, 117 (1/2), 105116.

GANOVEX Team (1987), Geological map of north Victoria Land, Antarctica, 1:500 000. Explanatory notes, Geologisches Jahrb B66,779.

Ghiribelli B., M.-L. Frezzotti, and R. Palmeri (2002), Coesite in eclogites of the Lanterman Range (Antarctica): evidence from textural and Raman studies, European Journal of Mineralogy, 14, 355-360.

Gibson, G.M., and T.R. Ireland (1996), Extension of Delamerian (Ross) orogen into western New Zealand: evidence from zircon ages and implications for crustal growth along the Pacific margin of Gondwana, Geology, 24, 1087-1090.

Goodge, J.W., and R.D. Dallmeyer (1996), Contrasting Thermal Evolution within the Ross Orogen, Antarctica: Evidence from Mineral 40Ar/39Ar Ages, J. Geol., 104, 435-458.

Gutjahr M., J.D. Bradshaw, S. Weaver, C. Munker, and T. Ireland (2006), Provenance of Cambrian conglomerates from New Zealand: implications for the tectonomagmatic evolution of the SE Gondwana margin, J. Geol. Soc. Lond. 163, 997-1010.

Henjes-Kunst, F. (2003), Single-crystal Ar-Ar laser dating of detrital micas from metasedimentary rocks of the Ross orogenic belt at the Pacific margin of the Transantarctic Mountains, Antarctica, Abstr. 9th International Symposium on Antarctic Earth Sciences, Sept. 8-12, Potsdam, Germany.

Henjes-Kunst, F. and U. Schussler (2003), Metasedimentary Units of the Cambro-Ordovician Ross Orogen in Northern Victoria Land and Oates Land: Implications for Their Provenance and Geotectonic Setting from Geochemical and Nd-Sr Isotope Data, Terra Antarctica, 10(3), 105-128.

Jongens, R., J.D. Bradshaw, and A.P. Fowler (2003), The Balloon Melange, northwest Nelson: origin, structure, and emplacement, NZJGG, 46, 437-448.

Kleinschmidt, G. and F. Tessensohn (1987), Early palaeozoic westward directed subduction at the Pacific Margin of Antarctica, in Gondwana Six: Structure, Tectonics, and Geophysics, edited by G.D. McKenzie, pp. 89-105, American Geophysical Union, Washington D.C.

Münker C. (2000), The Isotope and Trace Element Budget of the Cambrian Devil River Arc System, New Zealand: Identification of Four Source Components, Journal of Petrology, 41 (6), 759-788.

Münker, C., and R. Cooper (1999), The Cambrian arc complex of the Takaka Terrane, New Zealand: an integrated stratigraphical, paleontological and geochemical approach, NZJGG, 42, 415-445.

Münker, C., and A.J. Crawford, (2000), Cambrian arc evolution along the SE Gondwana active margin: A synthesis from Tasmania-New Zealand-Australia-Antarctica correlations, Tectonics, 19, 415-432.

Palmeri R., B. Ghiribelli, G. Ranalli, F. Talarico, and C.A. Ricci, (2007), Ultrahigh-pressure metamorphism and exhumation of garnet-bearing ultramafic rocks from the lanterman Range (northern Victoria Land, Antarctica), Journal of metamorphic Geology, 25, 225-243.

Ricci, C.A., F. Talarico, R. Palmeri, G. Di Vincenzo, and P.C. Pertusati (1996), Eclogite at the Antarctic palaeo-Pacific active margin of Gondwana (Lanterman Range, northern Victoria Land, Antarctica), Antarctic Science 8(3), 277 - 280.

Rocchi, S., G. Capponi, L. Crispini, G. Di Vincenzo, C. Ghezzo, M. Meccheri, and R. Palmeri (2003), Mafic rocks at the Wilson-Bowers Terrane transition and within the Bowers Terrane: implications for a geodynamic model of the Ross Orogeny, Terra Antartica Reports, 9, 145-148.

Rocchi, S. S. Tonarini, P. Armienti, F. Innocenti, and P. Manetti (1998), Geochemical and isotopic structure of the early Palaeozoic active margin of Gondwana in northern Victoria Land, Antarctica, Tectonophysics, 284, 261-281.
Squire, R.J. and C.J.L. Wilson (2005), Interaction between collisional orogenesis and convergent-margin processes: evolution of the Cambrian proto-Pacific margin of East Gondwana, J. Geol. Soc. Lond, $162,749-761$.

Stump, E. (1995), The Ross Orogen of the Transantarctic Mountains. Cambridge, Cambridge University Press.

Weaver, S.D., J.D. Bradshaw, and M.G. Laird (1984) Geochemistry of Cambrian volcanics of the Bowers Supergroup and implications for the Early Palaeozoic tectonic evolution of northern Victoria Land, Antarctica. EPSL, 68, 128-140.

Wright, T.O., R.J. Ross, and J.E. Repetski (1984), Newly discovered youngest Cambrian or oldest Ordovician fossils from the Robertson Bay terrane (formerly Precambrian), northern Victoria Land, Antarctica, Geology, 12, 301 - 305. 